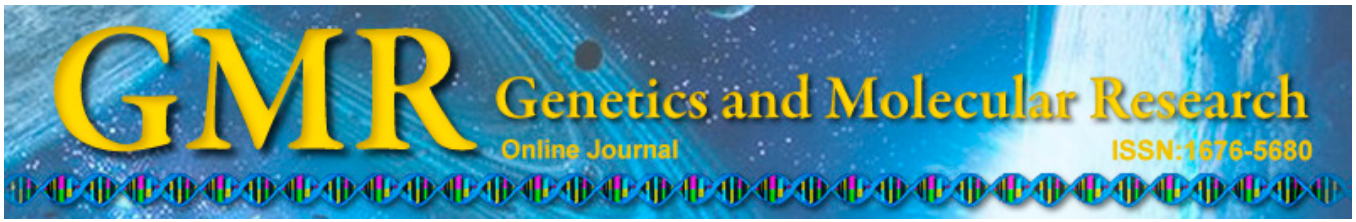

\title{
Investigation of Sclerotinia sclerotiorum strains variability in Brazil
}

\author{
M.J. Abreu and E.A. Souza \\ Departamento de Biologia, Universidade Federal de Lavras, Lavras, MG, Brasil \\ Corresponding author: E.A. Souza \\ E-mail: easouza@dbi.ufla.br
}

Genet. Mol. Res. 14 (2): 6879-6896 (2015)

Received October 15, 2014

Accepted February 26, 2015

Published June 18, 2015

DOI http://dx.doi.org/10.4238/2015.June.18.31

\begin{abstract}
White mold is a common bean disease caused by the fungus Sclerotinia sclerotiorum, resulting in economic losses in Brazil and worldwide. Lack of knowledge about the population structure of the pathogen makes it difficult to control the disease. The aim of this study was to characterize strains of $S$. sclerotiorum obtained from experimental and commercial common bean fields in Brazil. We analyzed 50 strains of $S$. sclerotiorum collected at several locations in the state of Minas Gerais. The strains were characterized according to their ability and time for developing apothecia. Morphological and physiological analyses such as the mycelial growth index, colony color, the time required to form the first sclerotia on media, the number of sclerotia per plate, average sclerotium size, and sclerotium shape were performed. We determined the mycelial compatibility, conducted molecular analysis of microsatellites, and evaluated the aggressiveness of 28 strains. Most strains had the ability to form apothecia. A small group of strains showed mycelial compatibility, and the strains showed different aggressiveness levels. Overall, the population studied here demonstrated wide variability based on the morphological, physiological, and molecular traits analyzed. The average size and shape of sclerotia presented a correlation of 0.617 , whereas the times required to form sclerotia and the number of sclerotia per plate showed a correlation of -0.455 . The char-
\end{abstract}


acterization of the pathogen population described herein will provide an important tool for promoting the development of bean cultivars resistant to white mold.

Key words: Sclerotinia sclerotiorum; Carpogenic germination; Mycelial compatibility group; Morphology characterization;

Microsatellite

\section{INTRODUCTION}

The common bean (Phaseolus vulgaris L.) crop in Brazil is subject to many biotic and abiotic stresses that cause expressive reductions in yield and affect the quality of the product. Among these, the actions of disease-causing plant pathogens stand out. White mold, caused by the fungus Sclerotinia sclerotiorum (Lib.) de Bary, interferes with the production of this crop in Brazil, especially in the Cerrado (tropical savanna) region (Ferraz et al., 1999) and in the winter season in irrigated areas.

Extensive damage to crops, absence of high levels of resistance in the hosts, and the great difficulty in controlling the diseases caused by S. sclerotiorum have stimulated research related to this fungus (Bolton et al., 2006). The problems associated with the evaluation of and selection for resistance to white mold may be due, in part, to the lack of knowledge of the pathogen population structure (Kull et al., 2004).

In population studies, markers are used to reveal existing variability, including mycelial compatibility groups (MCGs), DNA fingerprints, and microsatellite and amplified fragment length polymorphisms (AFLPs) (Kohn et al., 2008). In addition, morphological characteristics of the colony, mycelial growth rates, and traits of the sclerotia formed by the fungus provide additional information for analysis. Morphological characterization of the colonies and the sclerotia of $S$. sclerotiorum may be useful as a complementary descriptor in studies directed toward evaluating the variability of the pathogen (Lehner et al., 2011). Variability studies within populations in determined geographic regions are important since they might reveal the changes that occur in the populations over time (Akram et al., 2008).

Information regarding the biology of $S$. sclerotiorum populations is still emerging, with most arising from North America and Australia (Mert-Türk et al., 2007). Recently, studies have been performed in Brazil that have illustrated the variability that exists among the strains of S. sclerotiorum in that country (Gomes et al., 2011; Litholdo Júnior et al., 2011).

Litholdo Júnior et al. (2011) evaluated 40 S. sclerotiorum strains originating from diverse areas of Brazil and from different host crops using random amplified polymorphic DNA (RAPD) markers and MCGs. These strains were separated into three groups with similarity indices of $68.2,61.8$, and $61.8 \%$, and five MCGs. According to the authors, this was the first high-level report of variability of S. sclerotiorum in Brazil based on the study of strains of broad geographic origin, with the support of RAPD markers and MCGs. These results confirmed the prevalence of sexual reproduction of S. sclerotiorum in tropical and subtropical regions, in contrast with clonal reproduction in temperate regions.

A second study performed with 79 strains collected in the Brazilian Cerrado demonstrated the existing variability by use of microsatellite markers and polymerase chain reaction-restriction fragment length polymorphisms (PCR-RFLPs). The high variability identified within and among the populations was proposed to indicate the introduction of new genotypes 
in the areas analyzed, as well as the occurrence of clonal and sexual reproduction in the $S$. sclerotiorum populations in the Cerrado (Gomes et al., 2011).

In the absence of a susceptible host, survival structures, i.e., the sclerotia, are produced by the fungus. Sclerotia remain viable for more than eight years (Adams and Ayers, 1979) and may germinate in two different ways. Those that germinate in a myceliogenic manner produce hyphae that can directly attack plant tissues (Le Tourneau, 1979; Bardin and Huang, 2001), whereas in carpogenic germination there is production of apothecia and, afterwards, of ascospores that infect the plants. This germination is highly affected by soil temperature and moisture, which impact the number of stipes and apothecia produced (Hao et al., 2003).

It is necessary to perform studies of characterization of the strains of S. sclerotiorum that are obtained in experimental fields and that are commonly produced in Brazil. This information can assist plant breeding programs for the purpose of promoting resistance to white mold in the respective regions.

\section{MATERIAL AND METHODS}

This study was conducted in the Plant Disease Resistance Laboratory and in the Molecular Genetics Laboratory, both located in the Biology Department of the Universidade Federal de Lavras, Lavras, MG, Brazil.

\section{Collection and storage of sclerotia}

S. sclerotiorum strains were collected from experimental and commercial common bean fields in the state of Minas Gerais (Table 1).

Table 1. Sclerotinia sclerotiorum strains and their respective collection locations in the state of Minas Gerais.

\begin{tabular}{lllllll}
\hline Strain & Cultivar & Origin & Year & Strain & Cultivar & Origin \\
\hline UFLA1 & Talismã & Ijaci & 2009 & UFLA36 & Pérola & Guarda-Mor \\
UFLA2 & Talismã & Ijaci & 2009 & UFLA37 & - & Viçosa \\
UFLA3* & MAV 5.60 & Ijaci & 2009 & UFLA38 & - & Pesidente Bernardes \\
UFLA5* & - & Ijaci & 2009 & UFLA39 & - & - \\
UFLA6* & MAV 5.60 & Ijaci & 2009 & UFLA44* & Ouro Vermelho & Cabeceira Grande \\
UFLA7* & - & Ijaci & 2009 & UFLA45 & Pérola & Paracatu \\
UFLA8* & BRS executivo & Ijaci & 2009 & UFLA47 & Pérola & Paracatu \\
UFLA10* & Talismã & Ijaci & 2009 & UFLA48 & Ouro Vermelho & Porto Firme \\
UFLA11* & CNFP15 175 & Ijaci & 2009 & UFLA49 & Ouro Vermelho & Porto Firme \\
UFLA12* & - & Ijaci & 2009 & UFLA52* & - & Oratórios \\
UFLA13* & - & Ijaci & 2009 & UFLA54* & Ouro Vermelho & Viçosa \\
UFLA14* & MAV I-21 & Ijaci & 2009 & UFLA56* & - & Viçosa \\
UFLA15* & MAV 3.36 & Ijaci & 2009 & UFLA57* & - & Viçosa \\
UFLA18* & Talismã & Ijaci & 2009 & UFLA58 & - & Viçosa \\
UFLA19* & Talismã & Ijaci & 2009 & UFLA59 & Pérola & Unaí \\
UFLA20* & Talismã & Ijaci & 2009 & UFLA60 & Pérola & Unaí \\
UFLA21* & Talismã & Ijaci & 2009 & UFLA61 & - & Unaí \\
UFLA23* & Talismã & Ijaci & 2009 & UFLA63 & Pérola & Unaí \\
UFLA24* & Talismã & Ijaci & 2009 & UFLA64 & - & Unaí \\
UFLA25* & Talismã & Ijaci & 2009 & UFLA66 & - & Unaí \\
UFLA26 & Carioca & Lambari & 2010 & UFLA67 & - & Unaí \\
UFLA27* & - & Lambari & 2010 & UFLA77 & OPNS XVC 3 & Lambari \\
UFLA28* & - & Lamabri & 2010 & UFLA86 & - & Patos de Minas \\
UFLA30* & Carioca & Lambari & 2010 & UFLA91* & Majestoso & Patos de Minas \\
UFLA34 & Pérola & Paracatu & - & UFLA92* & Majestoso & Patos de Minas \\
\hline
\end{tabular}

*Indicates strains used in the aggressiveness evaluation. 
Sclerotia taken from plants and from the soil were stored in paper bags at room temperature. Afterwards, they were disinfected by immersion in $70 \%$ alcohol for 2 min and then in $1 \%$ sodium hypochlorite for $2 \mathrm{~min}$. Soon afterwards, they were washed in sterile distilled water for $2 \mathrm{~min}$. After disinfestation, the sclerotia were cultivated in a carrot-agar medium (Leslie and Summerell, 2006) at $22^{\circ} \mathrm{C}$. Each strain is derived from a single sclerotium. The strains were characterized and the sclerotia developed from cultivation in carrot-agar medium were used for induction of carpogenic germination for the purpose of obtaining the sexual phase of the fungus.

\section{Characterization of $S$. sclerotiorum strains}

\section{Carpogenic germination}

A total of 50 strains collected were evaluated for their capacity of and the time required for carpogenic germination using the modified methodology of Sun and Yang (2000). The ideal conditions described therein of high light intensity, high level of soil moisture and a temperature of $20^{\circ} \mathrm{C}$ were utilized. The methodology consisted of placing the sclerotia on the surface of moistened sterilized sand in growth layers with $12 \mathrm{~h}$ light per day until the formation of mature apothecia.

Tests were performed with two replications for each strain. Each replication consisted of a gerbox container $(11 \times 11 \times 3.5 \mathrm{~cm})$ containing sterilized sand and 15 sclerotia.

\section{Mycelial growth index (MGI)}

Colonized agar disks, taken from active growth cultures, were placed in 90-mm-diameter dishes containing potato dextrose agar (PDA) medium. The dishes were kept in the dark at a temperature of $22^{\circ} \mathrm{C}$. The diameters of the colonies $(\mathrm{mm})$ were measured daily (Mert-Türk et al., 2007).

The MGI was calculated using the formula adapted from Oliveira and Machado (1991):

\section{$\mathrm{MGI}=\sum(\mathrm{D}-\mathrm{Da})$ $\mathrm{N}$}

where $\mathrm{D}=$ current mean diameter of the colony; $\mathrm{Da}=$ mean diameter of the colony of the previous day; and $\mathrm{N}=$ number of days after inoculation.

The experiment was conducted using a completely randomized design with three replications, with each dish comprising a replication. The data obtained were subjected to analysis of variance using the GENES program (Cruz, 2006) and the mean values were compared by the Scott Knott test at $\mathrm{P} \leq 0.05$.

\section{Morphological characterization}

After thirty days of growth in PDA medium, the numbers of sclerotia formed per dish were analyzed for each strain. The sclerotia of each strain were characterized according to their form, and size; in addition, the colony color (Mert-Türk et al., 2007), as well as the time necessary for the formation of the first sclerotium of each strain was also evaluated. 
The experiments for morphological characterization of the strains were conducted and evaluated under the same conditions cited for the MGI. In addition, the correlations among these traits were evaluated and significance was tested by the Student $t$-test at $\mathrm{P} \leq 0.01$. For this evaluation, numerical values were attributed to each class of the traits, colony colors, and form of the sclerotia.

\section{MCGs}

Tests for determination of the MCGs were performed for all possible strain $\mathrm{x}$ strain combinations. A colonized PDA disk for each strain was transferred to a dish containing PDA medium modified with red food coloring $(300 \mu \mathrm{L} / \mathrm{L})$, pairwise, as described by Mert-Türk et al. (2007). The Petri dishes were maintained at $22^{\circ} \mathrm{C}$ for 5 days in the dark prior to evaluation.

Pairs of strains were considered incompatible when a region of contact between them was observed, characterized by the formation of a zone of red coloring. The pairs of strains in which it was not possible to verify the formation of the region of contact, indicating that their mycelia mixed in a uniform manner, were considered compatible. Each paired combination was repeated three times.

\section{Molecular characterization}

\section{DNA Extraction}

To obtain the mycelial mass, three agar disks were taken from an actively growing culture and transferred to $250-\mathrm{mL}$ Erlenmeyer flasks containing $150 \mathrm{~mL} 2 \%$ liquid malt medium. The flasks were kept in an incubator at $22^{\circ} \mathrm{C}$, with agitation at $120 \mathrm{rpm}$, for a period of time that ranged from three to four days, depending on the strain. The moisture of the mycelium obtained was reduced with the use of filter paper, and mycelium was later freeze-dried for $48 \mathrm{~h}$.

DNA extraction was performed using the methodology of Raeder and Broda (1985), as modified by Kaufman et al. (1999). Aliquots of DNA obtained from each strain were quantified on a $1 \%$ agarose gel. Through visual comparison of the intensity of the DNA bands, the concentration of each sample was estimated and afterwards diluted to a concentration of 10 $\mathrm{ng} / \mu \mathrm{L}$, which was used in the amplification reactions.

\section{Microsatellite analysis}

In this study, nine pairs of primers were used for microsatellite amplification (Table 2), which, as shown by Sirjusingh and Kohn (2001), are sufficient to display the polymorphism existing in a population of S. sclerotiorum.

The microsatellite amplification reactions contained $20 \mathrm{ng}$ genomic DNA, $100 \mu \mathrm{M}$ each deoxyribonucleotide (dATP, dGTP, dTTP, and dCTP), 1 U Taq DNA polymerase, $0.5 \mu \mathrm{M}$ of each primer of the pair, $2 \mu \mathrm{M}$ reaction buffer $(50 \mathrm{mM}$, Tris $\mathrm{pH} 8.3,2 \mathrm{mM} \mathrm{MgCl}, 20 \mathrm{mM}$ $\mathrm{KCl}, 10 \mu \mathrm{g}$ BSA, $0.25 \%$ Ficoll $400,10 \mathrm{mM}$ tartrazine) and double-distilled water, for a $12-\mu \mathrm{L}$ total reaction volume. Amplifications were performed in $0.2-\mathrm{mL}$ tubes in a Mastercycler Eppendorf model thermocycler (Eppendorf, Hamburg, Germany), using the following cycling conditions (Sirjusingh and Kohn, 2001): $95^{\circ} \mathrm{C}$ for $8 \mathrm{~min}$ initial denaturation, followed by 35 cycles denaturation at $95^{\circ} \mathrm{C}$, primer annealing at $47^{\circ}-55^{\circ} \mathrm{C}$ (Table 2), and extension at $72^{\circ} \mathrm{C}$ 
for 30-45 s, with 5-min extension in the final cycle. The amplified products were separated by electrophoresis on a polyacrylamide gel.

The polymorphic bands obtained with each pair of microsatellite primers were each given a score of 1 (presence of the band) or 0 (absence of the band) for each strain of the pathogen. The matrix generated was used to obtain estimates of genetic similarity using NTSYS software - pc 2.1 (Rolf, 2000).

Estimates of genetic similarity (sgij) among the strains were determined by the Sorensen-Dice coefficient by means of the expression sgij $=2 a /(2 a+b+c)$, with $a$ representing the presence of bands in the two genotypes $i$ and $j$; and $b$ and $c$ representing the presence of the band only in the individual strains $i$ or $j$, respectively. The similarity matrix was used to construct the dendrogram, and cluster analysis was performed by the unweighted pair-group method, arithmetic average (UPGMA) (Schneider et al., 2000). The errors associated with each similarity were estimated using the expression $\mathrm{sgs}=\{\mathrm{sgij}[(1-\mathrm{sgij}) /(\mathrm{n}-1)]\} 0.5$, in which $\mathrm{n}$ is the sum of $a, b$, and $c$ for each pair of strains. Strains belonging to different groups were identified in the dendrogram based on the estimate of the maximum significant similarity distance (sgm). The sgm was estimated by the $t$-test, using the expression $s g m=1-(t \mathrm{x} s g s)$, in which $t$ is the standard value of the Student $t$-distribution at $1 \%$ probability, with $\mathrm{n}-2$ degrees of freedom, and $s g s$ is the mean error of the comparisons considered in the dendrogram.

Table 2. Primers used for microsatellite detection.

\begin{tabular}{|c|c|c|c|}
\hline Primers FR & Repetitive sequences amplified & Primer sequence $\left(5^{\prime}-3^{\prime}\right)$ & Annealing temperature $\left({ }^{\circ} \mathrm{C}\right)$ \\
\hline \multirow[t]{2}{*}{ Primer set 1} & $(\mathrm{GT})_{8}$ & F: GTA ACA CCG AAA TGA CGG C & \\
\hline & & R: GAT CAC ATG TTT ATC CCT GGC & 55 \\
\hline \multirow[t]{2}{*}{ Primer set 2} & $(\mathrm{CA})_{9}$ & F: CGA TAA TTT CCC CTC ACT TGC & \\
\hline & & R: GGA AGT CCT GAT ATC GTT GAG G & 55 \\
\hline \multirow[t]{2}{*}{ Primer set 3} & {$\left[(\mathrm{GT})_{2} \mathrm{GAT}\right]_{3}(\mathrm{GT})_{14} \mathrm{GAT}(\mathrm{GT})_{5}$} & F: CAG ACG AAT GAG AAG CGA AC & \\
\hline & {$\left[\mathrm{GAT}(\mathrm{GT})_{4}\right]_{3}(\mathrm{GAT})_{3}$} & R: TTC AAA ACA ACG CTC CTG G & 55 \\
\hline \multirow[t]{2}{*}{ Primer set 4} & $(\mathrm{GT})_{10}$ & F: CCT GAT ATC GTT GAG GTC G & \\
\hline & & R: ATT TCC CCT CAC TTG CTC C & 55 \\
\hline \multirow[t]{2}{*}{ Primer set 5} & $(\mathrm{TTA})_{9}$ & F: TCA TAG TGA GTG CAT GAT GCC & \\
\hline & & R: CAG GGA TGA CTT TGG AAT GG & 47 \\
\hline \multirow[t]{2}{*}{ Primer set 6} & $\mathrm{TACA}_{10}$ & F: GTT TTC GGT TGT GTG CTG G & \\
\hline & & R: GCT CGT TCA AGC TCA GCA AG & 55 \\
\hline \multirow[t]{2}{*}{ Primer set 7} & $(\mathrm{CATA})_{25}$ & F: TGC ATC TCG ATG CTT GAA TC & \\
\hline & & R: CCT GCA GGG AGA AAC ATC AC & 55 \\
\hline \multirow[t]{2}{*}{ Primer set 8} & $(\text { TATG })_{9}$ & $\mathrm{~F}:$ ATC CCT AAC ATC CCT AAC GC & \\
\hline & & R: GGA GAA TTG AAG AAT TGA ATG C & 55 \\
\hline \multirow[t]{2}{*}{ Primer set 9} & $(\mathrm{AGAT})_{14}(\mathrm{AAGC})_{4}$ & F: GCT CCT GTA TAC CAT GTC TTG & \\
\hline & & R: GGA CTT TCG GAC ATG ATG AT & 55 \\
\hline
\end{tabular}

\section{Evaluation of $S$. sclerotiorum strain aggressiveness}

From the $50 \mathrm{~S}$. sclerotiorum strains used in this study, we determined an aggressiveness level of 28 (Table 1). For this, G122 (resistant) and Corujinha (susceptible) common bean cultivars were used.

One experiment was conducted in a randomized complete block design with a factorial scheme $(28 \times 2)$ with three replications. Each plot consisted of a vase of three liters with three plants.

To obtain mycelium for inoculation, disks of colonized agar with mycelium of each strain were transferred to plates containing PDA medium that were maintained at $22^{\circ} \mathrm{C}$ for four 
days. For inoculation, disks were removed from colonized medium using plastic micropipette tips. The method of inoculation utilized was the straw test proposed by Petzoldt and Dickson (1996).

The inoculation was performed at 28 days after seeding. The vases with inoculated plants were maintained in a greenhouse at $16^{\circ} \mathrm{C}$ during the night, and $24^{\circ} \mathrm{C}$ during the day, with $70 \%$ relative humidity (Pérez-Vega et al., 2012).

Seven days after inoculation, the disease severity was evaluated using a diagrammatic scale from 1 to 9 . Average values of nodes per plot were submitted to variance analysis using the GENES program and compared by the Scott Knott test at $\mathrm{P} \leq 0.05$.

\section{RESULTS}

\section{Carpogenic germination}

Of the 50 strains, $44 \%$ produced apothecia at around 35 days of incubation at $20^{\circ} \mathrm{C}$. At 46 days of incubation, an additional $24 \%$ were in the phase of appearance of the first stipes of the apothecia, whereas the other $32 \%$ of the strains had not germinated in a carpogenic manner (Table 3).

\begin{tabular}{|c|c|c|}
\hline Germination in 35 days & Germination in 46 days & No germination \\
\hline $\begin{array}{l}\text { UFLA1, UFLA2, } \\
\text { UFLA3, UFLA13, } \\
\text { UFLA15, UFLA25, } \\
\text { UFLA26, UFLA28, } \\
\text { UFLA30, UFLA37, } \\
\text { UFLA39, UFLA45, } \\
\text { UFLA48, UFLA56, } \\
\text { UFLA59, UFLA60, } \\
\text { UFLA61, UFLA63, } \\
\text { UFLA66, UFLA86, } \\
\text { UFLA91, UFLA92 }\end{array}$ & $\begin{array}{l}\text { UFLA5, UFLA7, } \\
\text { UFLA14, UFLA18, } \\
\text { UFLA20, UFLA21, } \\
\text { UFLA24, UFLA38, } \\
\text { UFLA47, UFLA54, } \\
\text { UFLA57, UFLA77 }\end{array}$ & $\begin{array}{l}\text { UFLA6, UFLA8, } \\
\text { UFLA10, UFLA11, } \\
\text { UFLA12, UFLA19, } \\
\text { UFLA23, UFLA27, } \\
\text { UFLA34, UFLA36, } \\
\text { UFLA44, UFLA49, } \\
\text { UFLA52, UFLA58, } \\
\text { UFLA64, UFLA67 }\end{array}$ \\
\hline
\end{tabular}

\section{MGI}

Variance analysis of the mean MGI values of the 50 S. sclerotiorum strains showed that there was a significant difference among them. The Scott Knott test separated the strains into four distinct groups according to their mycelial growth rates (Table 4). The two slowest growing strains were UFLA20 and UFLA23, which exhibited an average growth rate of 14.75 $\mathrm{mm} /$ day. Most of the strains showed a higher MGI, ranging from 23.83 to $30.17 \mathrm{~mm} /$ day.

\section{Morphological characterization}

Growth of the strains in PDA medium was monitored daily, and after 30 days they were characterized for colony color. Three distinct categories of predominant coloring were observed when colonies developed on the PDA medium: white, beige, and from brown to black (Figure 1). Of the 50 strains, 22\% (11) showed white colony coloring, 58\% (29) showed beige coloring, and 20\% (10) showed coloring from brown to black (Table 5). 
Table 4. Clustering results (groups A-D) of the mean values of the mycelial growth indices (MGIs) (mm/day) of 50 Sclerotinia sclerotiorum strains using the Scott Knott test, $\mathrm{P} \leq 0.05$.

\begin{tabular}{|c|c|c|c|c|c|}
\hline Strain & MGI/group & Strain & MGI/ group & Strain & MGI/ group \\
\hline UFLA1 & $24.00 \mathrm{D}$ & UFLA23 & $15.00 \mathrm{~A}$ & UFLA52 & $22.00 \mathrm{C}$ \\
\hline UFLA2 & $18.33 \mathrm{~B}$ & UFLA24 & $25.83 \mathrm{D}$ & UFLA54 & $26.67 \mathrm{D}$ \\
\hline UFLA3 & $27.67 \mathrm{D}$ & UFLA25 & $21.00 \mathrm{C}$ & UFLA56 & $25.50 \mathrm{D}$ \\
\hline UFLA5 & $26.83 \mathrm{D}$ & UFLA26 & $27.83 \mathrm{D}$ & UFLA57 & $27.83 \mathrm{D}$ \\
\hline UFLA6 & $26.83 \mathrm{D}$ & UFLA27 & $30.17 \mathrm{D}$ & UFLA58 & $26.83 \mathrm{D}$ \\
\hline UFLA7 & $29.50 \mathrm{D}$ & UFLA28 & $25.50 \mathrm{D}$ & UFLA59 & $27.00 \mathrm{D}$ \\
\hline UFLA8 & $26.83 \mathrm{D}$ & UFLA30 & $27.83 \mathrm{D}$ & UFLA60 & $25.00 \mathrm{D}$ \\
\hline UFLA 10 & $28.00 \mathrm{D}$ & UFLA34 & $27.33 \mathrm{D}$ & UFLA61 & $19.50 \mathrm{~B}$ \\
\hline UFLA11 & $27.67 \mathrm{D}$ & UFLA36 & $26.33 \mathrm{D}$ & UFLA63 & $25.50 \mathrm{D}$ \\
\hline UFLA12 & $28.83 \mathrm{D}$ & UFLA37 & $26.67 \mathrm{D}$ & UFLA64 & $24.83 \mathrm{D}$ \\
\hline UFLA13 & $28.50 \mathrm{D}$ & UFLA38 & $23.83 \mathrm{D}$ & UFLA66 & $26.50 \mathrm{D}$ \\
\hline UFLA14 & $26.83 \mathrm{D}$ & UFLA39 & $22.50 \mathrm{C}$ & UFLA67 & $25.67 \mathrm{D}$ \\
\hline UFLA15 & $29.17 \mathrm{D}$ & UFLA44 & $28.17 \mathrm{D}$ & UFLA77 & $27.17 \mathrm{D}$ \\
\hline UFLA18 & $22.83 \mathrm{C}$ & UFLA45 & $26.67 \mathrm{D}$ & UFLA86 & $26.17 \mathrm{D}$ \\
\hline UFLA19 & $21.16 \mathrm{C}$ & UFLA47 & $26.17 \mathrm{D}$ & UFLA91 & $25.00 \mathrm{D}$ \\
\hline UFLA20 & $14.50 \mathrm{~A}$ & UFLA48 & $25.50 \mathrm{D}$ & UFLA92 & $22.00 \mathrm{C}$ \\
\hline UFLA21 & $23.00 \mathrm{C}$ & UFLA49 & $27.00 \mathrm{D}$ & & \\
\hline
\end{tabular}

Group A: 14.50 - $15.00 \mathrm{~mm} /$ day; Group B: 18.33 - $19.50 \mathrm{~mm} /$ day; Group C: 21.00 - $23.00 \mathrm{~mm} /$ day; Group D: $23.83-30.17 \mathrm{~mm} /$ day.

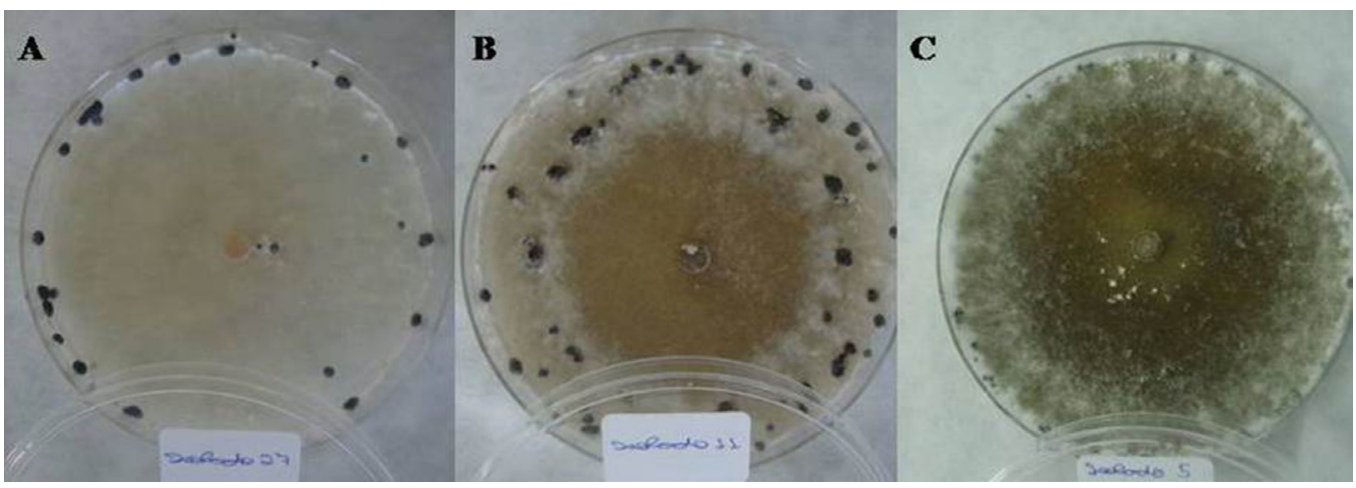

Figure 1. Color of the Sclerotinia sclerotiorum colonies in PDA medium after 30 days of growth. A) White coloring; B) beige coloring; C) brown to black coloring. PDA, potato dextrose agar.

Table 5. Colony color of 50 Sclerotinia sclerotiorum strains in PDA medium after 30 days of growth.

\begin{tabular}{lll}
\hline White coloring $(22 \%)$ & Beige coloring $(58 \%)$ & Coloring from brown to black (20\%) \\
\hline UFLA3, UFLA8, & UFLA1, UFLA5, & UFLA2, UFLA14, \\
UFLA21, UFLA26, & UFLA6, UFLA7, & UFLA19, UFLA38, \\
UFLA27, UFLA30, & UFLA10, UFLA11, & UFLA47, UFLA48, \\
UFLA37, UFLA39, & UFLA12, UFLA13, & UFLA49, UFLA56, \\
UFLA60, UFLA64, & UFLA15, UFLA18, & UFLA63, UFLA91 \\
UFLA77 & UFLA20, UFLA23, & \\
& UFLA24, UFLA25, & \\
& UFLA28, UFLA34, & \\
& UFLA36, UFLA44, & \\
& UFLA45, UFLA52, & \\
& UFLA54, UFLA57, & \\
& UFLA58, UFLA59, & \\
& UFLA67, UFLA66, & \\
& UFLA92 & \\
\hline
\end{tabular}

$\mathrm{PDA}=$ potato dextrose agar. 
The time necessary for formation of the first sclerotium of each strain was also analyzed and variance analysis of these data showed there was a significant difference among the 50 strains evaluated $(\mathrm{P} \leq 0.05)$. The Scott Knott test separated the strains into four distinct groups (Table 6), and the strains that were delayed most in formation of the first sclerotium were UFLA25, UFLA37, and UFLA39, with an average time necessary for these strains of 12.44 days. The strains that most rapidly formed the first sclerotium were UFLA1, UFLA6, UFLA7, UFLA10, UFLA11, UFLA12, UFLA13, UFLA15, UFLA52, UFLA54, UFLA57, and UFLA58, with formation of the first sclerotium at around the fourth day of incubation.

Table 6. Clustering results (groups A-D) of the mean values of the number of days to formation of the first sclerotia of 50 Sclerotinia sclerotiorum strains by the Scott Knott test, $\mathrm{P} \leq 0.05$.

\begin{tabular}{|c|c|c|c|c|c|}
\hline Strain & $\begin{array}{l}\text { Time to formation of } \\
\text { the first sclerotia/group }\end{array}$ & Strain & $\begin{array}{l}\text { Time to formation of the } \\
\text { first sclerotia/ group }\end{array}$ & Strain & $\begin{array}{l}\text { Time to formation of the } \\
\text { first sclerotia/ group }\end{array}$ \\
\hline UFLA1 & $4.67 \mathrm{~A}$ & UFLA23 & $7.33 \mathrm{C}$ & UFLA52 & $4.33 \mathrm{~A}$ \\
\hline UFLA2 & $7.67 \mathrm{C}$ & UFLA24 & $9.33 \mathrm{C}$ & UFLA54 & $4.33 \mathrm{~A}$ \\
\hline UFLA3 & $6.33 \mathrm{~B}$ & UFLA25 & $12.33 \mathrm{D}$ & UFLA56 & $5.67 \mathrm{~B}$ \\
\hline UFLA5 & $5.67 \mathrm{~B}$ & UFLA26 & $7.33 \mathrm{C}$ & UFLA57 & $4.00 \mathrm{~A}$ \\
\hline UFLA6 & $4.00 \mathrm{~A}$ & UFLA 27 & $6.00 \mathrm{~B}$ & UFLA58 & $4.33 \mathrm{~A}$ \\
\hline UFLA7 & $4.00 \mathrm{~A}$ & UFLA28 & $8.33 \mathrm{C}$ & UFLA59 & $5.00 \mathrm{~B}$ \\
\hline UFLA8 & $5.33 \mathrm{~B}$ & UFLA30 & $9.67 \mathrm{C}$ & UFLA60 & $6.33 \mathrm{~B}$ \\
\hline UFLA 10 & $4.67 \mathrm{~A}$ & UFLA34 & $5.33 \mathrm{~B}$ & UFLA61 & $5.33 \mathrm{~B}$ \\
\hline UFLA11 & $4.00 \mathrm{~A}$ & UFLA36 & $6.67 \mathrm{~B}$ & UFLA63 & $6.00 \mathrm{~B}$ \\
\hline UFLA 12 & $4.00 \mathrm{~A}$ & UFLA37 & $13.00 \mathrm{D}$ & UFLA64 & $7.33 \mathrm{C}$ \\
\hline UFLA 13 & $4.00 \mathrm{~A}$ & UFLA38 & $8.00 \mathrm{C}$ & UFLA66 & $5.67 \mathrm{~B}$ \\
\hline UFLA14 & $6.33 \mathrm{~B}$ & UFLA39 & $12.00 \mathrm{D}$ & UFLA67 & $6.67 \mathrm{~B}$ \\
\hline UFLA 15 & $4.00 \mathrm{~A}$ & UFLA44 & $5.33 \mathrm{~B}$ & UFLA77 & $5.33 \mathrm{~B}$ \\
\hline UFLA18 & $8.00 \mathrm{C}$ & UFLA45 & $8.00 \mathrm{C}$ & UFLA86 & $6.33 \mathrm{~B}$ \\
\hline UFLA 19 & $7.00 \mathrm{C}$ & UFLA47 & $7.33 \mathrm{C}$ & UFLA91 & $6.00 \mathrm{~B}$ \\
\hline UFLA20 & $8.67 \mathrm{C}$ & UFLA 48 & $6.33 \mathrm{~B}$ & UFLA92 & $6.33 \mathrm{~B}$ \\
\hline UFLA2 1 & $5.33 \mathrm{~B}$ & UFLA49 & $6.00 \mathrm{~B}$ & & \\
\hline
\end{tabular}

Group A: 4.00 - 4.67 days; Group B: 5.00 - 6.67 days; Group C: 7.00 - 9.67 days; Group D: 12.00 - 13.00 days.

Evaluation of the sclerotia of the 50 strains demonstrated a significant difference among the number of sclerotia per dish and among the average size of the sclerotia from each strain $(\mathrm{P} \leq 0.05)$. In addition, two distinct forms of sclerotia were found. The Scott Knott test separated the strains into two distinct groups in regard to the number of sclerotia formed per Petri dish (Table 7), with the number of sclerotia/dish ranging from 10.33 (UFLA47) to 46 (UFLA63).

In relation to the average size of the sclerotia from each strain, the Scott Knott test separated the 50 strains into three groups (Table 8). The strains that presented the largest and smallest mean sizes of the sclerotia were UFLA24 $(5.33 \mathrm{~mm})$ and UFLA91 $(2.03 \mathrm{~mm})$, respectively. Most strains (82\%) showed regular, circular sclerotia. Only UFLA20, UFLA24, UFLA30, UFLA36, UFLA49, UFLA52, UFLA56, UFLA57, and UFLA77 showed irregular and elongated sclerotia.

The mean size of the sclerotia and their form showed a correlation of 0.617 . Sclerotia with irregular and elongated format were generally larger. The times necessary for formation of the first sclerotia and the mean number of sclerotia per dish showed an inverse correlation of -0.455 . This negative value indicated that the greater the time necessary for formation of sclerotia, the fewer were formed per dish (Table 9). 
Table 7. Clustering results (groups A-B) of the mean values of the numbers of sclerotia per dish of 50 Sclerotinia sclerotiorum strains by the Scott Knott test, $\mathrm{P} \leq 0.05$.

\begin{tabular}{|c|c|c|c|c|c|}
\hline Strain & $\begin{array}{l}\text { No. of sclerotia } \\
\text { per dish/group }\end{array}$ & Strain & $\begin{array}{l}\text { No. of sclerotia } \\
\text { per dish/ group }\end{array}$ & Strain & $\begin{array}{l}\text { No. of sclerotia } \\
\text { per dish/group }\end{array}$ \\
\hline UFLA1 & $24.67 \mathrm{~A}$ & UFLA23 & $18.00 \mathrm{~A}$ & UFLA52 & $31.67 \mathrm{~B}$ \\
\hline UFLA2 & $17.00 \mathrm{~A}$ & UFLA24 & $29.00 \mathrm{~B}$ & UFLA54 & $40.00 \mathrm{~B}$ \\
\hline UFLA3 & $25.67 \mathrm{~A}$ & UFLA25 & $14.00 \mathrm{~A}$ & UFLA56 & $23.67 \mathrm{~A}$ \\
\hline UFLA5 & $24.33 \mathrm{~A}$ & UFLA26 & $19.00 \mathrm{~A}$ & UFLA57 & $31.33 \mathrm{~B}$ \\
\hline UFLA6 & $36.00 \mathrm{~B}$ & UFLA27 & $39.67 \mathrm{~B}$ & UFLA58 & $20.67 \mathrm{~A}$ \\
\hline UFLA7 & $42.00 \mathrm{~B}$ & UFLA28 & $21.00 \mathrm{~A}$ & UFLA59 & 29.33 B \\
\hline UFLA8 & $29.00 \mathrm{~B}$ & UFLA30 & $20.00 \mathrm{~A}$ & UFLA60 & $23.67 \mathrm{~A}$ \\
\hline UFLA10 & $43.67 \mathrm{~B}$ & UFLA34 & $34.00 \mathrm{~B}$ & UFLA61 & 29.33 B \\
\hline UFLA11 & $42.67 \mathrm{~B}$ & UFLA36 & $15.00 \mathrm{~A}$ & UFLA63 & $46.00 \mathrm{~B}$ \\
\hline UFLA12 & $34.67 \mathrm{~B}$ & UFLA37 & $13.33 \mathrm{~A}$ & UFLA64 & $28.00 \mathrm{~B}$ \\
\hline UFLA13 & $35.67 \mathrm{~B}$ & UFLA38 & $29.33 \mathrm{~B}$ & UFLA66 & $13.67 \mathrm{~A}$ \\
\hline UFLA14 & $15.33 \mathrm{~A}$ & UFLA39 & $18.00 \mathrm{~A}$ & UFLA67 & $35.00 \mathrm{~B}$ \\
\hline UFLA15 & $29.00 \mathrm{~B}$ & UFLA44 & $19.00 \mathrm{~A}$ & UFLA77 & $15.33 \mathrm{~A}$ \\
\hline UFLA18 & $44.67 \mathrm{~B}$ & UFLA45 & $22.67 \mathrm{~A}$ & UFLA86 & $26.00 \mathrm{~A}$ \\
\hline UFLA19 & $14.33 \mathrm{~A}$ & UFLA47 & $10.33 \mathrm{~A}$ & UFLA91 & $17.33 \mathrm{~A}$ \\
\hline UFLA20 & $26.67 \mathrm{~A}$ & UFLA48 & $36.33 \mathrm{~B}$ & UFLA92 & $11.00 \mathrm{~A}$ \\
\hline UFLA21 & $28.00 \mathrm{~B}$ & UFLA49 & $21.00 \mathrm{~A}$ & & \\
\hline
\end{tabular}

Group A: 10.00 - 26.67 sclerotia per dish; Group B: 28.00 - 46.00 sclerotia per dish.

Table 8. Clustering results (groups A-C) of the mean values of the mean sclerotia sizes ( $\mathrm{mm}$ ) of 50 Sclerotinia sclerotiorum strains by the Scott Knott test, $\mathrm{P} \leq 0.05$.

\begin{tabular}{lccccc}
\hline Strain & Mean sclerotia size/group & Strain & Mean sclerotia size/ group & Strain & Mean sclerotia size/ group \\
\hline UFLA1 & $2.97 \mathrm{~A}$ & UFLA23 & $4.63 \mathrm{C}$ & UFLA52 & $4.73 \mathrm{C}$ \\
UFLA2 & $3.27 \mathrm{~A}$ & UFLA24 & $5.33 \mathrm{C}$ & UFLA54 & $2.63 \mathrm{~A}$ \\
UFLA3 & $2.83 \mathrm{~A}$ & UFLA25 & $3.80 \mathrm{~B}$ & UFLA56 & $4.30 \mathrm{C}$ \\
UFLA5 & $2.80 \mathrm{~A}$ & UFLA26 & $2.37 \mathrm{~A}$ & UFLA57 & $4.10 \mathrm{~B}$ \\
UFLA6 & $3.07 \mathrm{~A}$ & UFLA27 & $2.97 \mathrm{~A}$ & UFLA58 & $2.73 \mathrm{~A}$ \\
UFLA7 & $2.97 \mathrm{~A}$ & UFLA28 & $2.63 \mathrm{~A}$ & UFLA59 & $2.63 \mathrm{~A}$ \\
UFLA8 & $3.03 \mathrm{~A}$ & UFLA30 & $3.67 \mathrm{~B}$ & UFLA60 & $3.03 \mathrm{~A}$ \\
UFLA10 & $2.77 \mathrm{~A}$ & UFLA34 & $3.53 \mathrm{~B}$ & UFLA61 & $2.83 \mathrm{~A}$ \\
UFLA11 & $3.23 \mathrm{~A}$ & UFLA36 & $4.72 \mathrm{C}$ & UFLA63 & $2.97 \mathrm{~A}$ \\
UFLA12 & $2.63 \mathrm{~A}$ & UFLA37 & $3.37 \mathrm{~A}$ & UFLA64 & $3.58 \mathrm{~B}$ \\
UFLA13 & $3.17 \mathrm{~A}$ & UFLA38 & $3.17 \mathrm{~A}$ & UFLA66 & $2.80 \mathrm{~A}$ \\
UFLA14 & $4.60 \mathrm{C}$ & UFLA39 & $2.53 \mathrm{~A}$ & UFLA67 & $3.13 \mathrm{~A}$ \\
UFLA15 & $2.57 \mathrm{~A}$ & UFLA44 & $2.43 \mathrm{~A}$ & UFLA77 & $3.47 \mathrm{~A}$ \\
UFLA18 & $3.67 \mathrm{~B}$ & UFLA45 & $3.62 \mathrm{~B}$ & UFLA86 & $2.87 \mathrm{~A}$ \\
UFLA19 & $3.70 \mathrm{~B}$ & UFLA47 & $3.57 \mathrm{~B}$ & UFLA91 & $2.03 \mathrm{~A}$ \\
UFLA20 & $2.97 \mathrm{~A}$ & UFLA48 & $2.87 \mathrm{~A}$ & UFLA92 & $3.20 \mathrm{~A}$ \\
UFLA21 & $3.60 \mathrm{~B}$ & UFLA49 & $5.00 \mathrm{C}$ & &
\end{tabular}

Group A: 2.03 - $3.47 \mathrm{~mm}$; Group B: 3.53 - $4.10 \mathrm{~mm}$; Group C: 4.30 - $5.33 \mathrm{~mm}$.

Table 9. Correlations among the morphological traits of Sclerotinia sclerotiorum.

\begin{tabular}{|c|c|c|c|c|c|}
\hline Morphological characteristics & $\mathrm{CC}$ & TS & $\mathrm{SN}$ & MSS & EM \\
\hline$\overline{\mathrm{CC}}$ & & $-0.165^{\mathrm{NS}}$ & $-0.009^{\mathrm{NS}}$ & $0.185^{\mathrm{NS}}$ & $0.014^{\mathrm{NS}}$ \\
\hline TS & & & $-0.455^{*}$ & $0.170^{\mathrm{NS}}$ & $0.047^{\mathrm{NS}}$ \\
\hline NS & & & & $-0.163^{\mathrm{NS}}$ & $-0.126^{\mathrm{NS}}$ \\
\hline MSS & & & & & $0.617 *$ \\
\hline EM & & & & & \\
\hline
\end{tabular}

$\mathrm{CC}=$ colony color; $\mathrm{TS}=$ time to formation of the first sclerotia; $\mathrm{SN}=$ sclerotia number per dish; MSS = mean sclerotia size; $\mathrm{EM}=$ sclerotia morphology; NS = not significant by Student $t$-test, $\mathrm{P} \leq 0.01$; *significant by Student $t$-test, $\mathrm{P} \leq 0.01$ 


\section{MCGs}

A total of 2500 pairing combinations of the 50 strains were evaluated. Of these, only $157(6.28 \%)$ showed mycelial compatibility. The rest of the pairings showed a region of contact characterized by a zone of red coloring, thus proving the pairs incompatible (Figure 2).

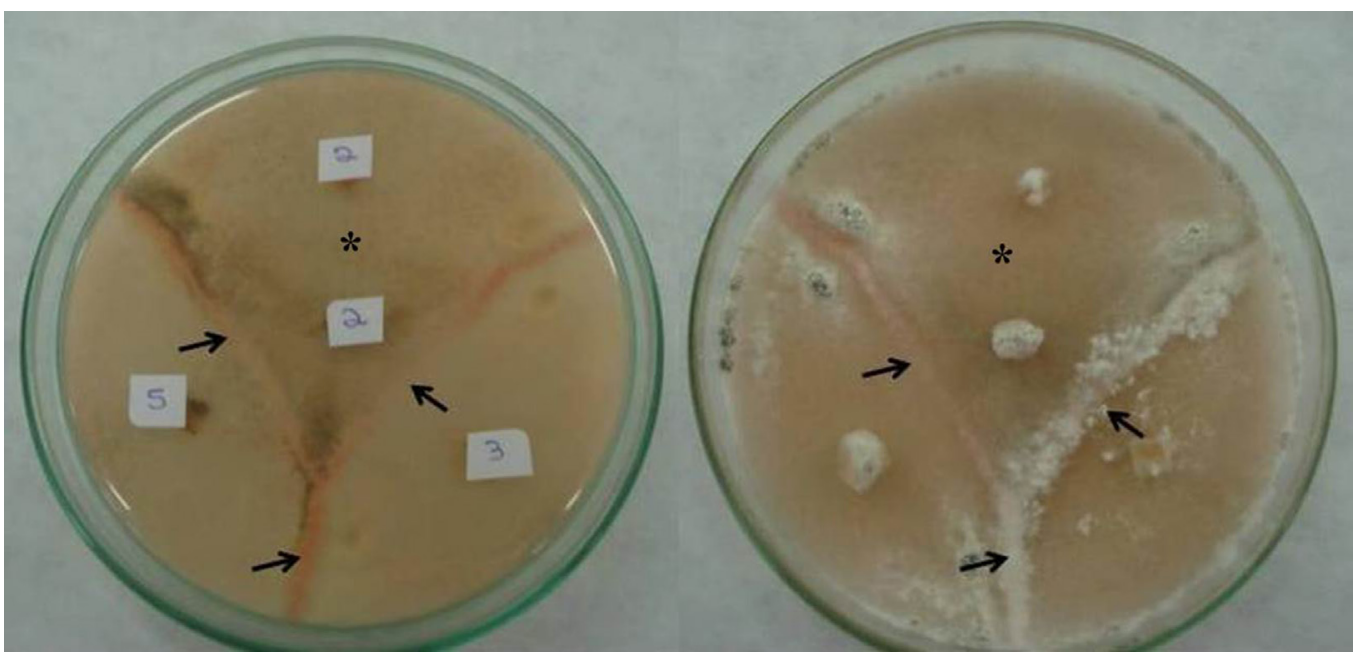

Figure 2. Representative example of pairings of Sclerotinia sclerotiorum strains in PDA medium modified with red food coloring. The arrows indicate regions of mycelia incompatibility and the asterisks indicate regions of compatibility. PDA, potato dextrose agar.

Among the strains evaluated, UFLA58 was not compatible with any other strain and showed self-incompatibility, whereas UFLA64 showed a greater number of compatible combinations, being compatible with nine other strains as well as itself (Table 10). Five strains (UFLA19, UFLA37, UFLA38, UFLA56, and UFLA63), in addition to UFLA58, showed self-incompatibility.

Table 10. Mycelial compatibility (MC) percentage of 50 Sclerotinia sclerotiorum strains.

\begin{tabular}{lcccc}
\hline Strain & \% MC & Strain & $\%$ MC & Strain \\
\hline UFLA1 & 6 & UFLA23 & 14 & UFLA52 \\
UFLA2 & 6 & UFLA24 & 8 & UFLA54 \\
UFLA3 & 2 & UFLA25 & 4 & UFLA56 \\
UFLA5 & 8 & UFLA26 & 4 & UFLA57 \\
UFLA6 & 10 & UFLA27 & 16 & UFLA58 \\
UFLA7 & 10 & UFLA28 & 2 & UFLA59 \\
UFLA8 & 16 & UFLA30 & 2 & UFLA60 \\
UFLA10 & 12 & UFLA34 & 6 & UFLA61 \\
UFLA11 & 10 & UFLA36 & 2 & UFLA63 \\
UFLA12 & 8 & UFLA37 & 2 & UFLA64 \\
UFLA13 & 6 & UFLA39 & 4 & UFLA66 \\
UFLA14 & 6 & UFLA44 & 8 & UFLA67 \\
UFLA15 & 4 & UFLA45 & 6 & UFLA77 \\
UFLA18 & 2 & UFLA47 & 4 & UFLA91 \\
UFLA19 & 2 & UFLA48 & 6 & UFLA92 \\
UFLA20 & 4 & UFLA49 & 2 & 2 \\
UFLA21 & 6 & & & 20 \\
\hline
\end{tabular}




\section{Molecular analysis by microsatellites}

The nine pairs of primers used to amplify microsatellites displayed polymorphism within the population, amplifying a total of 45 polymorphic bands and generating, on average, five polymorphic bands per primer set. An example of one of the band patterns generated is shown in Figure 3.

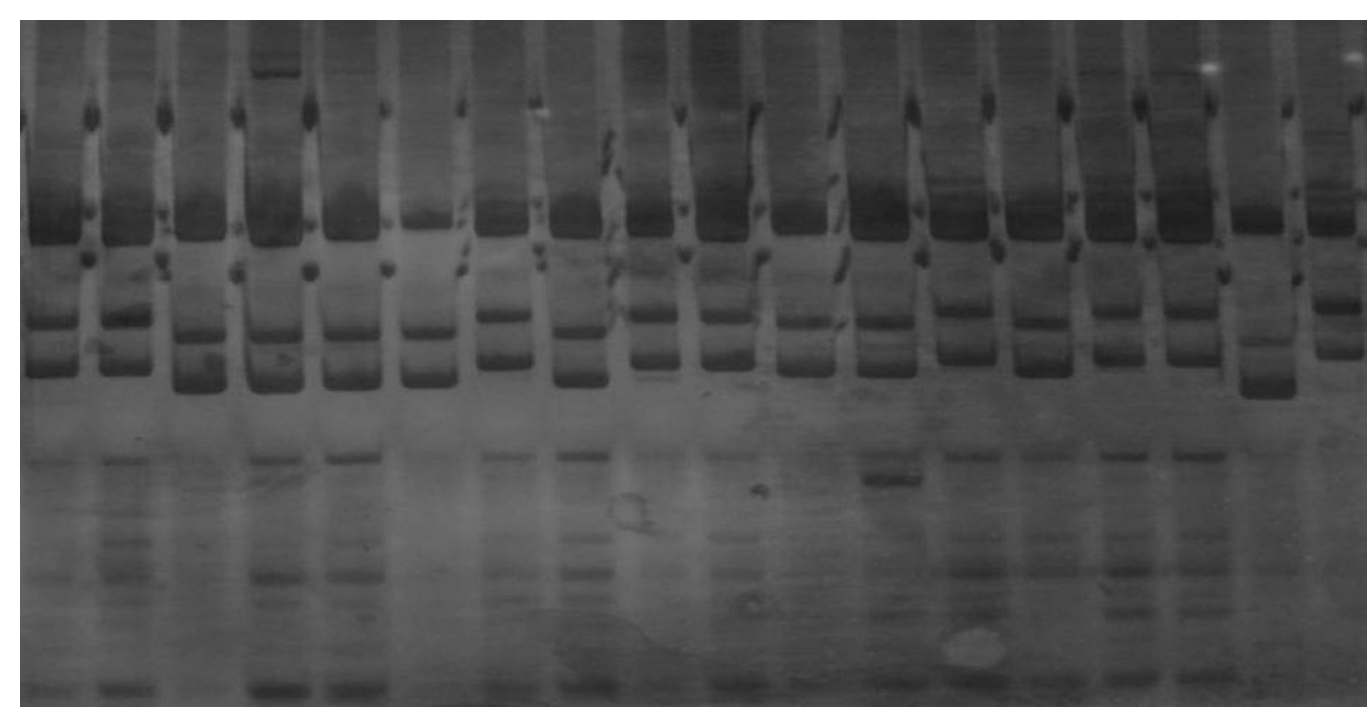

Figure 3. Pattern of microsatellite bands generated by primer set 3 . The image depicts an inverted electropherogram.

Based on the 45 polymorphic bands, a matrix of 0 s and $1 \mathrm{~s}$ was constructed, and using the Sorensen-Dice coefficient, estimates of genetic similarities were obtained, which ranged from 0.3 to 0.92 . A dendrogram was constructed for better visualization (Figure 4). The cutoff line, given by the sgm estimate at $1 \%$ probability by the $t$-test, was 0.77 . Analysis of the dendrogram resulted in the formation of 35 groups. Only three groups contained more than two strains considered genetically similar: group XIII (UFLA60, UFLA61, and UFLA63), group XVII (UFLA38, UFLA44, UFLA, UFLA45, UFLA47, and UFLA48), and group XXIII (UFLA6, UFLA10, and UFLA8), highlighting the high genotypic variability of the strains evaluated.

\section{Evaluation of $S$. sclerotiorum strain aggressiveness}

In the variance analysis of the average reaction scores of the two cultivars to the 28 strains of S. sclerotiorum, the strain source of variation and the interaction between cultivar $\mathrm{x}$ strain were significant $(\mathrm{P} \leq 0.05)$.

The average aggressiveness scores of strains varied from 1.27 (UFLA14) to 6.39 (UFLA56). The UFLA30, UFLA44, and UFLA56 strains formed a group of more aggressive strains, while UFLA14 and UFLA20 showed a lower level of aggressiveness (Table 11). 


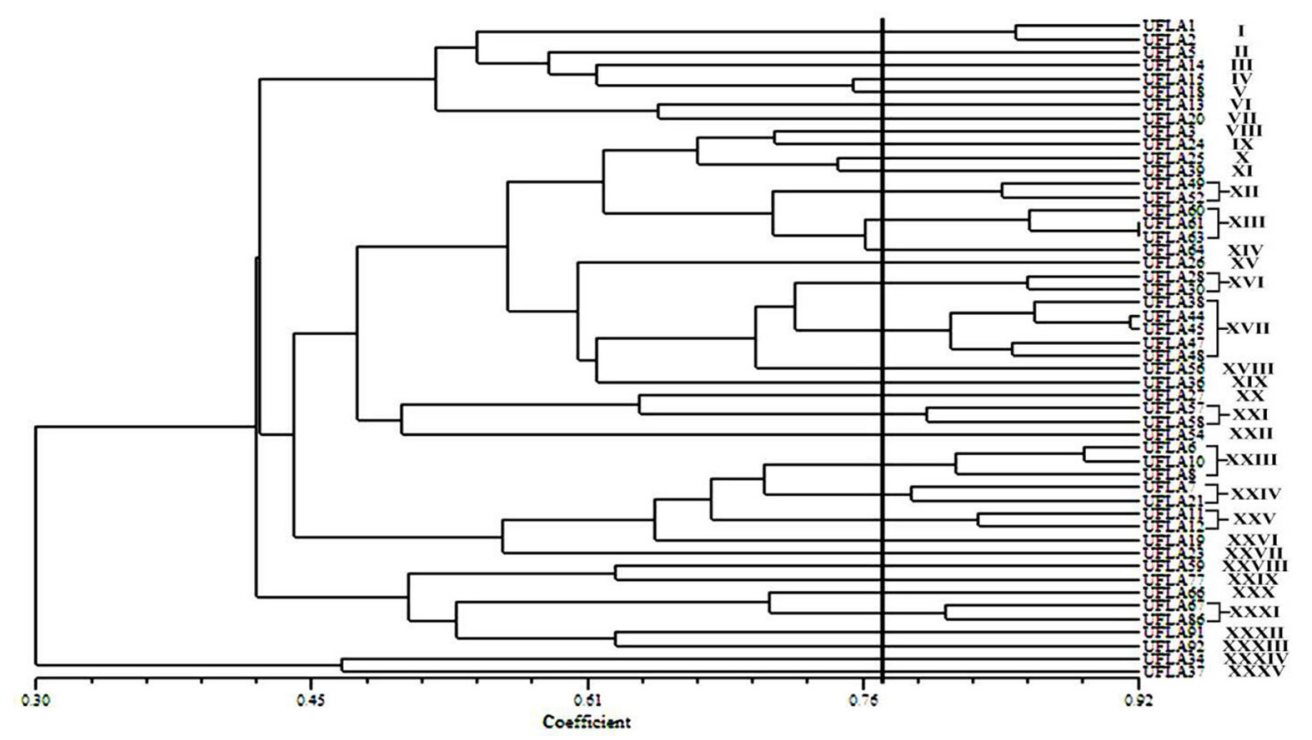

Figure 4. Dendrogram of the genetic similarity of 50 Sclerotinia sclerotiorum strains with a cutoff line of 0.77 , determined by the sgm estimate at $1 \%$ probability ( $t$-test). Sgm, maximum significant similarity distance.

Table 11. Clustering results (groups A-D) of the mean values of the aggressiveness of 28 Sclerotinia sclerotiorum strains against common bean cultivars by the Scott Knott test, $\mathrm{P} \leq 0.05$.

\begin{tabular}{|c|c|c|c|}
\hline Strain & G 122/group & Corujinha/group & Mean/group \\
\hline UFLA 3 & $4.33 \mathrm{~A}$ & $4.33 \mathrm{C}$ & $4.33 \mathrm{~B}$ \\
\hline UFLA 5 & $3.07 \mathrm{~A}$ & $4.17 \mathrm{C}$ & $3.62 \mathrm{~B}$ \\
\hline UFLA 6 & $4.10 \mathrm{~A}$ & $4.50 \mathrm{C}$ & $4.30 \mathrm{~B}$ \\
\hline UFLA 7 & $4.17 \mathrm{~A}$ & $4.50 \mathrm{C}$ & $4.34 \mathrm{~B}$ \\
\hline UFLA 8 & $4.10 \mathrm{~A}$ & $3.67 \mathrm{C}$ & $3.89 \mathrm{~B}$ \\
\hline UFLA 10 & $3.93 \mathrm{~A}$ & $4.00 \mathrm{C}$ & $3.97 \mathrm{~B}$ \\
\hline UFLA 11 & $4.43 \mathrm{~A}$ & $4.27 \mathrm{C}$ & $4.35 \mathrm{~B}$ \\
\hline UFLA 12 & $3.67 \mathrm{~A}$ & $4.40 \mathrm{C}$ & $4.04 \mathrm{~B}$ \\
\hline UFLA 13 & $4.10 \mathrm{~A}$ & $4.67 \mathrm{C}$ & $4.39 \mathrm{~B}$ \\
\hline UFLA 14 & $1.20 \mathrm{~B}$ & $1.33 \mathrm{D}$ & $1.27 \mathrm{C}$ \\
\hline UFLA 15 & $4.23 \mathrm{~A}$ & $4.90 \mathrm{C}$ & $4.57 \mathrm{~B}$ \\
\hline UFLA 18 & $3.87 \mathrm{~A}$ & $4.90 \mathrm{C}$ & $4.39 \mathrm{~B}$ \\
\hline UFLA 19 & $4.33 \mathrm{~A}$ & $3.77 \mathrm{C}$ & $4.05 \mathrm{~B}$ \\
\hline UFLA 20 & $1.50 \mathrm{~B}$ & $1.77 \mathrm{D}$ & $1.64 \mathrm{C}$ \\
\hline UFLA 21 & $4.67 \mathrm{~A}$ & $4.07 \mathrm{C}$ & $4.37 \mathrm{~B}$ \\
\hline UFLA 23 & $4.40 \mathrm{~A}$ & $4.67 \mathrm{C}$ & $4.54 \mathrm{~B}$ \\
\hline UFLA 24 & $5.37 \mathrm{~A}$ & $3.77 \mathrm{C}$ & $4.57 \mathrm{~B}$ \\
\hline UFLA 25 & $4.33 \mathrm{~A}$ & $3.87 \mathrm{C}$ & $4.10 \mathrm{~B}$ \\
\hline UFLA 27 & $3.90 \mathrm{~A}$ & $4.00 \mathrm{C}$ & $3.95 \mathrm{~B}$ \\
\hline UFLA 28 & $4.10 \mathrm{~A}$ & $3.87 \mathrm{C}$ & $3.99 \mathrm{~B}$ \\
\hline UFLA 30 & $4.67 \mathrm{~A}$ & $6.37 \mathrm{~B}$ & $5.52 \mathrm{~A}$ \\
\hline UFLA 44 & $4.67 \mathrm{~A}$ & $5.77 \mathrm{~B}$ & $5.22 \mathrm{~A}$ \\
\hline UFLA 52 & $3.50 \mathrm{~A}$ & $4.17 \mathrm{C}$ & $3.84 \mathrm{~B}$ \\
\hline UFLA 54 & $4.00 \mathrm{~A}$ & $4.37 \mathrm{C}$ & $4.19 \mathrm{~B}$ \\
\hline UFLA 56 & $5.57 \mathrm{~A}$ & $7.20 \mathrm{~A}$ & $6.39 \mathrm{~A}$ \\
\hline UFLA 57 & $4.10 \mathrm{~A}$ & $4.80 \mathrm{C}$ & $4.45 \mathrm{~B}$ \\
\hline UFLA 91 & $4.50 \mathrm{~A}$ & $4.23 \mathrm{C}$ & $4.37 \mathrm{~B}$ \\
\hline UFLA 92 & $4.70 \mathrm{~A}$ & $4.17 \mathrm{C}$ & $4.44 \mathrm{~B}$ \\
\hline Mean/group & $4.05 \mathrm{~A}$ & $4.30 \mathrm{~A}$ & \\
\hline
\end{tabular}

Cultivars groups: Group A: 4.05 - 4.30. Strains groups: Group A: 5.22 - 6.39; Group B: 3.62 - 4.57; Group C: 1.27 - 1.64. 


\section{DISCUSSION}

Evaluation of the 50 strains of $S$. sclerotiorum showed that there was genetic variation in regard to the capability of and time for occurrence of their carpogenic germination. This variation was not related to the location from where the strains were collected, with strains from different origins germinating at the same period of time and strains originating from the same location forming apothecia at different times. As the conditions for conducting the experiments were the same for all strains, this variation was most likely due to genetic differences between them.

According to the methodology described by Sun and Yang (2000), carpogenic germination of the sclerotia occurs at approximately two months. These two months are in reference to the pre-conditioning process of the sclerotia at $4.5^{\circ} \mathrm{C}$. However, this study demonstrated that the pre-conditioning process is not necessary since, upon placement of the sclerotia directly on the surface of sterile sand, formation of apothecia occurred in 35 days.

Evaluation of apothecia production is important since the apothecia, resulting from the carpogenic germination of sclerotia, are the major source of inoculation of the fungus because they produce a large quantity of ascospores (Steadman, 1983). Nevertheless, there is no information regarding the production of apothecia by strains collected from the common bean. Mylchreest and Wheeler (1987) evaluated 35 strains of S. sclerotiorum from colza in regard to production of apothecia, and they observed $100 \%$ carpogenic germination, although the time necessary for formation of stipes varied considerably.

Some data have shown that a correlation exists between the sclerotia size and apothecium production. Dillard et al. (1995), performing studies on green beans, showed that medium to large size sclerotia produce more apothecia than do small ones. According to Bolton et al. (2006), the sclerotia of S. sclerotiorum vary a great deal in size, depending on the host. A survey of the literature performed by Bag (1999) showed that sclerotia ranged from 2-11 mm on various hosts. In this study, the medium size of the sclerotia fell within this size variation, and ranged from 2.03-5.33 $\mathrm{mm}$ in diameter. However, no relationship was observed between the occurrence of carpogenic germination and sclerotia size.

The MGI of the strains evaluated ranged from 14.5 (UFLA20) to $30.17 \mathrm{~mm} /$ day (UFLA27) and the time for formation of the first sclerotium ranged from 4 to 13 days. These data revealed the variability existing among the strains with respect to these traits. Akram et al. (2008), upon evaluation of 16 strains of S. sclerotiorum from chickpeas, demonstrated variation in the radial growth of the strains, which were classified into three groups (rapid, intermediate, and slow growth). According to this classification, 39 of the 50 strains (78\%) evaluated in this study showed rapid colony growth.

Of the 11 strains that most rapidly formed the first sclerotium, 10 were among those that showed a greater MGI. This comparison is pertinent since the formation of sclerotia occurs after mycelial growth in a nutrient-limited environment (Christias and Lockwood, 1973).

Evaluation of sclerotia numbers demonstrated that 27 of the 50 strains (54\%) formed a reduced number of sclerotia, ranging from 10.33 to 26.67 sclerotia per dish. The others strains presented from 28 to 46 sclerotia/dish, on average. This variation is within the range expected, as Lehner et al. (2011) previously identified from 9 to 59 sclerotia per dish in 30 strains also taken from the common bean in fields in the state of Minas Gerais.

Sclerotia produced by $S$. sclerotiorum strains found in cabbage are mainly regular and circular (Bag, 1999). The sclerotia produced by most of the 50 strains in this study also 
exhibited regular and circular morphology. Only nine strains showed irregular and elongated morphology. The sclerotial morphology groups did not have any relationship to the size of the sclerotia from each strain, nor to the number of sclerotia per dish.

Three distinct colony colorings (beige, brown to black, and white) were observed for the strains; most showed predominantly beige colonies. Lehner et al. (2011) also observed these three main colony colorings; however, most of the strains in their study developed white colonies. It is important to note that the culture medium used in that study and in the present study was the same (PDA), as colony color might be affected by the culture medium used to cultivate the fungus.

Evaluation of mycelial compatibility of the 50 strains studied found only a small percentage of compatible strains $(6.28 \%)$. This result demonstrates that there was considerable variability among the genotypes evaluated. Most strains were self-compatible; however, six self-incompatible strains were identified. No relationship was identified between strain compatibilities and their sites of origin.

Similarly, no relationship to geographic origin was identified in the study of Litholdo Júnior et al. (2011), in which 40 S. sclerotiorum strains originating from various regions of Brazil and from different crops were evaluated. The mycelia compatibility study separated the strains into five distinct groups. Comparing these results with those of the present study, it can be observed that the diversity found in present study is greater, reconfirming the genetic variability found among strains obtained from the same host (common bean) and from a smaller collection region.

Otto-Hanson et al. (2011) evaluated 156 S. sclerotiorum strains taken from the common bean, both from the field and from the greenhouse, and they identified 64 groups of mycelial compatibility, of which more than half were composed of only one strain. These data demonstrate great diversity even among strains taken from the greenhouse, revealing the great extent of variability that can be found in pathogen populations even in restricted collection areas.

The nine pairs of microsatellite primers used in the present study were also used by Sirjusingh and Kohn (2001) in a study of strains from North America, primarily from Canada. Eight of the nine pairs were also used by Mert-Türk et al. (2007) to study colza strains in Turkey. Analysis of the molecular data of present study demonstrated high genotypic variability among the strains as 35 groups were generated, most (25) formed from a single strain.

In another study performed with $79 \mathrm{~S}$. sclerotiorum strains collected from the common bean in the Brazilian Cerrado, 10 pairs of microsatellite primers were used, eight of which were polymorphic. Analyses based on genetic diversity and on fixation indices indicated variability among and within populations. These data suggested that the intrapopulational gene flow level was high, which indicated that the white mold in the common bean crop in the Brazilian Cerrado was caused by genetically diverse $S$. sclerotiorum populations, and that this pathogen was highly variable within small geographic areas (Gomes et al., 2011).

Molecular analysis of the strains evaluated in the present study, together with the morphological and physiological characteristics presented, shows that there is also great variability among and within $S$. sclerotiorum populations in the locations analyzed in Minas Gerais. The groupings of the strains in reference to their morphological and physiological traits, as well as molecular analysis, did not have any relationship to their locations of origin.

Therefore, we highlight here the strains that originated from the municipality of Ijaci, which were collected in a single crop area. Of the 50 strains evaluated, $20(40 \%)$ were of this origin and showed variability in all traits analyzed. Among these, the time necessary for car- 
pogenic germination stands out because the strains showed greater variability between them. According to the groupings based on strain similarity as determined by microsatellite analysis, 15 groups were formed among the 20 strains, with three being composed of only two strains and one composed of three. The other eleven strains of this origin formed distinct groups comprised of only one strain each.

Wide variability present in the pathogen population becomes an important concern in common bean breeding programs designed to develop white mold control. However, the search for resistance under field conditions is often problematic without the assistance of artificial inoculation (Zhao et al., 2004). The reaction evaluation of the two common bean cultivars to $28 \mathrm{~S}$. sclerotiorum strains showed that the strains exhibited different aggressiveness levels. The UFLA30, UFLA44, and UFLA56 strains were more aggressive, while the UFLA14 and UFLA20 strains formed a group with a lower level of aggressiveness. No significant difference was observed between the Corujinha and G122 cultivar reactions, even though G122 is considered a standard of pathogen resistance; however, cultivar $\mathrm{x}$ strain interactions were significant. Pratt and Rowe (1995) evaluated the reaction of nine alfalfa cultivars to five $S$. sclerotiorum strains which showed differences in their aggressiveness level; in this case, however, cultivar $\mathrm{x}$ strain interactions were not observed. The experiment in the present study was conducted under greenhouse conditions with favorable environmental conditions for fungus development, whereas studies using G122 as a classic resistant cultivar were conducted in the field, without temperature and humidity control (Miklas et al., 2001). Furthermore, G122 is unadapted to the environmental conditions of Brazil and has been used in crosses with adapted common bean lines that have favorable traits such as high productivity and grain type.

High variability of strains of $S$. sclerotiorum found within and between field locations can influence the disease phenotype of putative white mold resistant germplasm (Otto-Hanson et al., 2011). Once the most aggressive strains have been identified, these should be used for the discrimination of common bean genotypes with higher resistance levels. Furthermore, the characterization of the S. sclerotiorum population structure and variability in aggressiveness among strains can guide the development of strategies for disease management.

Comparisons between the aggressiveness results of the strains with the results found in the microsatellite analysis and the evaluation of the MCG did not identify any relationship among them. For example, some compatible strains showed different aggressiveness levels, while other incompatible strains showed similar aggressiveness levels. Similar results were found for Zancan (2014), working with 25 S. sclerotiorum strains of different dry bean cultivars from several states in Brazil, also found differences in aggressiveness levels of strains belonging to the same MCG. In contrast, Otto-Hanson et al. (2011), working with $156 \mathrm{~S}$. sclerotiorum isolates collected both in the greenhouse and field from common beans in the United States, only found differences among strains in different MCGs and not among strains in the same MCG.

S. sclerotiorum has a sexual cycle and most of the strains used in this study were capable of producing apothecia. The sexual cycle is important in the generation of variability and in the evolutionary potential of pathogen populations (Chen and Mcdonald, 1996). Nevertheless, this pathogen has homothallic behavior (Bolton et al., 2006). Therefore, it is important to investigate which mechanisms are generating variability, the importance of the sexual phase in the generation of variability, and if homothallic behavior is really predominant in this species. It is also important to understand the genetic population structure of S. sclerotiorum in the common bean since the variability found in our study was quite substantial even in a small 
collection area, as could be seen in the strains originating from Ijaci.

The common bean is cultivated in three seasons in Brazil. The first is known as the wet season, the second is called the dry season, and the third is the irrigated crop season (MAPA, 2012). White mold has greater incidence in winter in irrigated areas, but has been found in all three crop seasons, thus being one of the diseases of greatest importance to this crop in the country.

Studies directed toward characterization of S. sclerotiorum strains in regard to morphology, physiology, and molecular traits are rare. This is the first report of a study linking all these traits for strains collected from common bean in a region of Brazil, which enables a better perspective of the variability of the pathogen population within a single geographic region. Overall, the characterization of pathogen populations in the state of Minas Gerais, evaluated in the present study, will provide a very important tool to assist in the development of white mold resistant common bean cultivars.

\section{ACKNOWLEDGMENTS}

We would like to thank Coordenação de Aperfeiçoamento de Pessoal de Nível Superior - CAPES, and Conselho Nacional de Desenvolvimento Científico e Tecnológico - CNPq (\#481269/2009-6).

\section{REFERENCES}

Adams PB and Ayers WA (1979). Ecology of Sclerotinia spp. Phytopathology 69: 896-899.

Akram A, Iqbal SM, Ahmed N, Iqbal U, et al. (2008). Morphological variability and mycelial compatibility among the isolates of Sclerotinia Sclerotiorum associated with stem rot of chickpea. Pak. J. Bot. 40: 2663-2668.

Bag TK (1999). Notes on the variation of sclerotial structure of Sclerotinia sclerotiorum (Lib) De Bary, incitant of cabbage head rot. ENVIS Bulletin: Himalayan Ecology 7. Avaliable at http://gbpihedenvis.nic.in/html/vol71/NOTES\%20 ON\%20THE\%20VARIATION.pdf.

Bardin SD and Huang HC (2001). Research on biology and control of Sclerotinia diseases in Canada. Can. J. Plant Pathol. 23: 88-98.

Bolton MD, Thomma BPHJ and Nelson BD (2006). Sclerotinia sclerotiorum (Lib.) de Bary: biology and molecular traits of a cosmopolitan pathogen. Mol. Plant Pathol. 7: 1-16.

Chen RS and Mcdonald BA (1996). Sexual reproduction plays a major role in the genetic structure of populations of the fungus Mycosphaerella graminicola. Genetics 142: 1119-1127.

Christias C and Lockwood JL (1973). Conversion of mycelial constituents in four sclerotium-forming fungi in nutrient deprived conditions. Phytopathology 63: 602- 605.

Cruz CD (2006). GENES. Programa Genes: Biometria. Editora UFV. Viçosa (MG). 382p.

Dillard HR, Ludwig JW and Hunter JE (1995). Conditioning Sclerotia of Sclerotinia sclerotiorum for carpogenic germination. Plant Dis. 79: 411-415.

Ferraz LCL, Café Filho AC, Nasser LCB and Azevedo JA (1999). Effects of soil moisture, organic matter and grass mulching on the carpogenic germination of sclerotia and infection of bean by Sclerotinia sclerotiorum. Plant Pathol. 48: 77-82.

Gomes EV, Nascimento LB, Freitas MA, Nasser LCB, et al. (2011). Microsatellite markers reveal genetic variation within Sclerotinia sclerotiorum populations in irrigated dry bean crops in Brazil. J. Phytopathol. 159: 94-99.

Hao JJ, Subbarao KV and Duniway JM (2003). Germination of Sclerotinia minor and S. sclerotiorum Sclerotia under various soil moisture and temperature combinations. Phytopathology 93: 443-450.

Kaufman B, Richards S and Dierig DA (1999). DNA isolation method for high polysaccharide Lesquerella species. Indust. Crop Prod. 9: 111-114.

Kohn LM, Schaffer MR, Anderson JB and Grünwald NJ (2008). Marker stability throughout 400 days of in vitro hyphal growth in the filamentous ascomycete, Sclerotinia sclerotiorum. Fungal Genet. Biol. 45: 613- 617.

Kull LS, Pedersen WL, Palmquist D and Hartman GL (2004). Mycelial compatibility grouping and aggressiveness of Sclerotinia sclerotiorum. Plant Dis. 88: 325- 332. 
Lehner MS, Paula Júnior TJ, Teixeira H, Vieira RF, et al. (2011). Morphological variability of Sclerotinia sclerotiorum sampled from bean fields in Minas Gerais State, Brazil. Annu. Rep. Bean Improv. Coop. 54: 128-129.

Le Tourneau D (1979). Morphology, cytology and physiology of Sclerotinia species in culture. Phytopathology 69: 887890.

Leslie JF and Summerell BA (2006). The Fusarium laboratory manual. Blackwell Publishing, Ames.

Litholdo Júnior CG, Gomes EV, Lobo Júnior M, Nasser LCB, et al. (2011). Genetic diversity and mycelial compatibility groups of the plant-pathogenic fungus Sclerotinia sclerotiorum in Brazil. Genet. Mol. Res. 10: 868-877.

MAPA. Ministério da Agricultura. Perfil do feijão no Brasil. Avaliable at: http://www.agricultura.gov.br/vegetal/culturas/ feijao/saiba-mais. Accessed June 8, 2012.

Mert-Türk F, Ipek M, Mermer D and Nicholson P (2007). Microsatellite and morphological markers reveal genetic variation within a population of Sclerotinia sclerotiorum from oilseed rape in the Çanakkale Province of Turkey. $J$. Phytopathol. 155: 182-187.

Miklas PN, Johnson WC, Delorme R and Gepts P (2001). QTL conditioning physiological resistance and avoidance to white mold in dry bean. Crop Sci. 41: 309-315.

Mylchreest SJ and Wheeler BEJ (1987). A method for inducing apothecia from sclerotia of Sclerotinia sclerotiorum. Plant Pathol. 36: 16-20.

Oliveira JA and Machado JC (1991). Efeito do tratamento fungicida em sementes no controle de tombamento de plântulas de pepino (Cucumis sativus L.) e pimentão (Capsium annum L.). Master's thesis, UFLA, Lavras.

Otto-Hanson L, Steadman JR, Higgins R and Eskridge KM (2011). Variation in Sclerotinia sclerotiorum bean isolates from multisite resistance screening locations. Plant Dis. 95: 1370-1377.

Pérez-Veja E, Pascual A, Campa A, Giraldez R, et al. (2012). Mapping quantitative trait loci conferring partial physiological resistance to white mold in the common bean RIL population Xana 3 Cornell 49242. Mol. Breeding 29: 31-41.

Petzoldt R and Dickson MH (1996). Straw test for resistance to white mold in beans. Annu. Rep. Bean Improv. Coop. 39: $142-143$.

Pratt RG and Rowe DE (1995). Comparative pathogenicity of isolates of Sclerotinia trifoliorum and S. sclerotiorum on alfalfa cultivars. Plant Dis. 79: 474-477.

Raeder U and Broda P (1985). Rapid preparation of DNA from filamentous fungi. Lett. Appl. Microbiol. 1: 17-20.

Rolf JF (2000). NTSYSpc. Numerical taxonomy and multivariate analysis system: version 2.1, Exeter Software. New York: Setauket.

Schneider S, Roessli D and Excoffier L (2000). Arlequin: a software for population genetics data analysis, user manual ver. 2.000. University of Geneva, Geneva.

Sirjusingh C and Kohn LM (2001). Characterization of microsatellites in the fungal plant pathogen, Sclerotinia sclerotiorum. Mol. Ecol. Notes 1: 267-269.

Steadman JR (1983). White mold - a serious yield-limiting disease of bean. Plant Dis. 67: 346-350.

Sun P and Yang XB (2000). Light, temperature, and moisture effects on apothecium production of Sclerotinia sclerotiorum. Plant Dis. 84: 1287-1293.

Zancan WLA (2014). Mofo-branco em algodão, girassol e feijão: potencial de transmissão e efeitos na qualidade de sementes e variabilidade do patógeno. Doctoral thesis, UFLA, Lavras. Available at: http://repositorio.ufla.br/jspui/ handle/1/1745.

Zhao J, Peltier AJ, Meng J, Osborn TC, et al. (2004). Evaluation of Sclerotinia stem rot resistance in oilseed Brassica napus using a petiole inoculation technique under greenhouse conditions. Plant Dis. 88: 1033-1039. 